\title{
RETURN SPILLOVER BETWEEN THE U.S., JAPANESE, AND INDONESIAN STOCK MARKET DURING COVID-19
}

\author{
Cynthia Sari Dewi \\ Universitas Multimedia Nusantara, Banten, Indonesia \\ cynthia.sari@umn.ac.id \\ Florentina Kurniasari \\ Universitas Multimedia Nusantara, Banten, Indonesia \\ florentina@umn.ac.id \\ Helena Dewi \\ Universitas Multimedia Nusantara, Banten, Indonesia \\ helena.dewi@lecturer.umn.ac.id \\ Eko Endarto \\ Universitas Multimedia Nusantara, Banten, Indonesia \\ ekoendarto@gmail.com \\ Nurhuda Nizar \\ Universiti Teknologi Mara, Alam Selangor, Malaysia \\ hudanizar@uitm.edu.my
}

\begin{abstract}
The Covid-19 pandemic brings effects to global stock market. Information from one country is integrated to the whole world which causes the return transmission between stock markets. This research investigates the return spillover effect between the US (S\&P 500), Japanese (Nikkei 225), and Indonesian (JCl) stock market during the peak of Covid-19 pandemic period. Data is examined using Eviews version 12 with Granger-causality test. Results show that S\&P 500 and Nikkei 225 indexes influence the return of JCl, but not the other way around. On top of that, S\&P 500 and Nikkei 225 indexes influence each other. Moreover, results also indicate that information about Covid-19 is integrated between the US, Japanese, and Indonesian stock market hence affecting the return in JCl. These findings are useful to investors and policymakers regarding to US and Japan economic information which can influence return in $\mathrm{JCl}$.
\end{abstract}

Keywords: return spillover, stock market, covid-19 effect, Granger-causality.

DOI: https://doi.org/10.24818/beman/2021.S.I.2-15 


\section{INTRODUCTION}

A country's economy can be reflected in its stock market because the stock market performs two functions at a time, which is economic function and investment function. Looking from the economic view, the fund circulation in the stock market brings together investors and issuers. On the other hand, from the investment side we can see that there is a chance to get a return that is appropriate with the chosen investment characteristics, hence return is an important factor that is considered by investors in their investment decision (Pakpahan, 2003).

Generally, one of the factors that affect the movement of the stock market are news and announcements. If a country experiences a worrying or satisfactory condition, its stock exchange will move greatly. Especially if the announcement is made for the whole world, not only one country will flare up, but also all the stock markets in every different country will face the pressure first as this is because return in different stock markets is all connected to each other. Even if there is an unpredictable shock or "global shock", markets will show strong integration with stock price movements whether in developed or developing countries (Joshi, 2011). Research about the relationship between the stock market helps investors and policy makers regarding the information to make investment decisions. Generally, investors will diversify stocks, where their stock portfolio consists of several different assets to minimize risk. However, if the stock market between countries is strongly integrated to one another, one stock market will influence the movements of other stock markets, the benefit of portfolio diversification becomes hard to reach (Nikmanesh, et al., 2014).

Spillover effect is resulted from return and volatility that spreads from one market to another (Choo, Loo, Ling \& Ung, 2011), even with the analysis of return and volatility in stock market reflects the healthiness and stability of stock market depending on the country's economy so it provides information for the investors and government [Zhou, Zhang \& Zhang (2012); Mala \& Reddy (2007)]. Not only that, return spillover analysis in the stock market became a phenomenon among finance researchers because various results were found. Some research about spillover between developed market to developing market are confirmed in many studies in many countries [Ishfaq \& Rehman (2018); (Huo \& Ahmed (2018)]. It is also supported by some research explanations that the US and Japanese stock market have the main market influences the other stock markets, including developing countries [Ngunyen \& Lee (2018); (Wang \& Liu (2012)].

Covid-19 pandemic is an international issue in which until January 1, 2021, 90 million cases and 1,90 million death cases are recorded and still growing (Worldometer, 2021). It affects health, the way people work, survive, and finance, including the stock market. International Management Portfolio is defending against fear of pandemic that will break international portfolio values in the long term. In the US and Japanese market, the performance of both stock markets was recorded to be lower during Covid-19 outbreak and there was short term shock lowering stock value, but in the long term it went back to its previous level and 
even reached its new level peak (Yan, Tu, Start \& Zhang, 2020). The effect on US and Japanese stocks caused by Covid-19 pandemic parallel happened around 25 first trade days after the release of pandemic news in each country (Avalos \& Zakrajsek, 2020). Meanwhile, the effect on developing countries, which in this case is Malaysia, revealed that there was significant overreaction in the stock market in the short term period as the effect of pandemic (SARS) (Ali, et al., 2021). After the announcement of the Indonesian Government on March 2, 2020, which stated that there were two Indonesians infected by the Coronavirus, Indonesia Stock Exchange (IDX) went down 1,68\% to IDR 5361,25 (Rakhmawati \& Nurhalim, 2021). Moreover, in mid March 2020 IDX went down to its lowest point at 4907,571 or equal to $-22,10 \%$ (Shiyammurti, et al., 2020). The study conducted by Hestiawan, Prijadi (2020) found that in 2018 Asian Markets were still low at only $14.08 \%$ and connectedness in developing markets was only $2.9 \%$ and the return spillover factor of the Asian markets has a stronger influence on returns compared to the local market. Also during European Sovereign Debt Crisis indicate that intra-EMU stock market return spillover was higher than the intra-non-EMU European Union stock markets' return spillover during the crisis period (Qarni \& Gulzar, 2020). Moreover, studies found that the global financial crisis has strengthened the linkages among stock markets in East Asia, while the influences of the US market became weaker during and after the crisis (Wang, 2014). Similar findings are found by Panda et al. (2021) which stated that among the stock market in Asia-Pacific region, there is a faint return spillover effect during the pre-crisis period while in comparison, there is a significantly greater return spillover during the post-crisis period with the highest pairwise directional return spillover was evident from Thailand to Indonesia and the Philippines, from Indonesia to the Philippines, and between Australia and New Zealand. Regarding the period during Covid-19 crisis, the study by Hung \& Vo (2021) found that the Covid-19 outbreak is resulting in more apparent return transmission compared to the pre-Covid-19 period. It is also found that the information spillovers among the S\&P 500, crude oil markets, and gold markets are considered as significant dependent patterns which might provide useful implications for portfolio managers, investors, and government agencies.

The return transmission in all stock markets was very varied during the Covid-19 pandemic. Investigating the return spillover effect from the US and Japanese stock market to developing countries such as Indonesia is very important. Therefore, stock returns in the US and Japanese market must become a great concern to the Indonesian stock market, hence this research is conducted to examine the influence of return spillover from the US and Japanese stock market to Indonesian stock market with focus during the peak of Covid-19 outbreak. 


\section{LITERATURE REVIEW}

\section{The Efficient Market Theory}

The Efficient Market Theory (EMH) is a classical theory that defines a market that has three forms in which is affected by historical data, public and private information. A market is described as a perfect market if all the information given can move stock prices. This theory stated that investors will not trade undervalued stocks or sell stocks at high prices. Assets price in the efficient market contains all related information, hence assets price from an efficient market moves towards the equilibrium faster when the market experiences shock (Fama, 1991). Information that has been publicized from one market to another can influence all markets simultaneously but surely the significance will be different in each market (King $\&$ Wadhani, 1990). Different stock markets can reveal the same information but at different speed because of the market imperfections (Kyle, 1985). Besides, Admati \& Pfleiderer (1988) added, local investors need to react to external information because that information is obtained after the trade ends. As a matter of fact, information transfer can occur from several sources, such as (1) common shock, (2) trade linkages, (3) financial linkages, and (4) investor's sentiment (Caramazza, et al., 2004). Barry (2015) explains that volatility and return from two equity markets probably will connect with each other because of the close relationship of the trade, investment link, financial market integration growth, ICAPM model, and market contagion.

\section{Return Spillover}

Spillover is a tendency of volatility change in a certain market following the other changes of another market because of information transfer (Brooks, 2008). Investors nowadays tend to like spreading news about return and volatility information because of the arising financial integration all over the world (Yousaf, Ali \& Wong, 2020). That is why the information about return spillover is treated as important by the investors. Spillover effects result from return and volatility between stock markets (Choo et al., 2011). Return spillover can be defined as a transmission of return between stock markets. Such a phenomenon has occurred as stated by Shahzad et al. (2021) where in the light of the Covid-19 outbreak, extreme return spillover was examined. According to Ciner, (2011) and Zhou, Lu \& Wang (2014), in this case the Granger-causality test is a useful tool to examine return spillovers between different financial markets. Various research and studies have been conducted to investigate the return spillover, one of them is investigating the effect of the US and Japanese stock market to the Vietnamese stock market. Results from Granger-causality test showed that the US stock market has a significant but indirectional effect on Vietnamese stock market, also that the Japanese stock market has significant directional effect on Vietnamese stock market (Ngunyen \& Lee, 2018). 
In line with those findings, researchers (Huo \& Ahmed, 2018) used the Granger-causality test to examine return spillover from Shanghai and Hong Kong stock market and found that there is a bidirectional relationship between Shanghai and Hong Kong stock market during the period of Pre-Stock Connect. Moreover, the return spillover is indicated as stronger and faster after the launch of ShanghaiHong Kong Stock Connect program. Regarding stock market networks: Temporal proximity and preferential attachment also used Granger causality model. It is found that the US market has influence on the other developed markets especially Canada, Portuguese, Austria, Netherlands, UK, and Belgium (Vyrost et al., 2015). Other research about return and volatility spillovers in BRICS stock market, through the Granger-causality test found that there is a bidirectional return spillover between the stock markets of India and Brazil, India and Russia, China and Russia, also Brazil and Russia. Not only that, there is also an indirectional spillover effect between the stock market of India and China, China and Brazil, South Africa and China, but also of India, Brazil and Russia (Panda \& Thiripalraju, 2018).

Equally so, Roni, Abbas \& Wang (2018) who investigated the return and volatility spillover in Asian emerging stock markets namely Bangladesh, China, India, Malaysia, Philippine, and South Korea, used the Granger-causality test to analyze the relationship among stock market and found that return spillovers are different during the period of pre-crisis, crisis, and post-crisis. The only exception in their result is that there is a bidirectional relationship between India and Bangladesh stock market during the period of precrisis and post-crisis. By the same token, Al-Yahyaee et al. (2019) found that there is a relationship between the US stock market and GIPSI (Greece, Ireland, Portuguese, Spain, and Italy) stock markets. Study that was conducted by Sun, Wang, Yao, Li \& Li (2020) stated that emerging countries have larger average spillovers than developed countries with regard to sovereign CDS-to-stock returns spillovers, while the developed countries contribute more to the average spillovers than the emerging countries in the opposite direction and the most dominant position is occupied by stock markets. Not only that, Uzonwanne (2021) found that there is a significant return spillover between stock markets and cryptocurrency, caused by the mitigation by investors between the market pairs to maximize returns and reduce risk. These findings are also supported by the study conducted by Hung (2021) where it is found that in the aftermath of the recent European debt crises and the global financial crisis, there is a bidirectional return spillover between economic policy uncertainty (EPU) and BRICS stock returns. Based on previous studies, this research has three hypotheses, there are:

$\mathrm{H} 1$ : There is a causal relationship between US and Indonesian stock return.

$\mathrm{H} 2$ : There is a causal relationship between Japanese and Indonesian stock return.

H3: There is a causal relationship between US and Japanese stock return. 


\section{RESEARCH METHODS}

This research analyzes empirically about return spillovers which focused on the US, Japanese, and Indonesian stock market during the period of Covid-19 pandemic. Data used for this research is the daily price of Standard and Poor's Index (S\&P 500), Nikkei 225, and Jakarta Composite Index (JCI) from 1 January 2020 to 30 June 2021 . The reason why this research is using daily price as a data source is to capture information about price change more accurately compared to weekly or monthly price data (Jebran \& Iqbal, 2016). The daily price is earned from various website, namely Yahoo Finance, and then changed into return (Rt) using equation below (Choo, Loo, Ling \& Ung, 2011):

$$
R_{t}=\frac{P_{t}-P_{t-1}}{P_{t-1}}
$$

where:

$P_{t}=$ today's closing price index

$P_{t-1}=$ today's closing price index -1 or yesterday's closing price index

Index consists of JCl; S\&P 500; Nikkei 225

Return spillover can be examined using time series causality test or Granger test (Granger, 1969) with Eviews statistical software version 12. This test can statistically determine whether a time series is useful to predict other things. Granger-causality test is a test to evaluate how much the current y can be explained by the past $y$ and lagged value of $x$. $y$ in this test can be said to be Granger-caused by $x$ if $x$ helped in predicting $y$, or equivalent to if the coefficient in lagged $x$ statistically significant. The lag length of the Johansen Test used in this study is 2. Granger-causality test can be done using Vector Auto Regression (VAR) as follows (Gujarati, 2004):

$$
\begin{aligned}
& y_{t}=\alpha_{0}+\alpha_{1} y_{t-1}+\beta_{1} x_{t-1}+\cdots+\beta_{1} x_{t-1}+\varepsilon_{t} \\
& x_{t}=\alpha_{0}+\alpha_{1} x_{t-1}+\beta_{1} y_{t-1}+\cdots+\beta_{1} y_{t-1}+\varepsilon_{t}
\end{aligned}
$$

and the null hypothesis for each equation is:

$$
\beta_{1}=\beta_{2}=\cdots=\beta_{t}=0
$$

The null hypothesis is that $x$ does not Granger-cause $y$ in the first regression and that $y$ does not Grangercause in $\mathrm{x}$ the second regression.

\section{FINDINGS AND RESULTS}

This research analyzes the return spillover from US and Japanese stock market to Indonesian stock market using the closing stock price index during the peak of Covid-19 pandemic period from 1 January 
Dewi, C., Kurniasari, F., Dewi, H., Endarto, E., Nizar, N. RETURN SPILLOVER BETWEEN THE U.S., JAPANESE, AND INDONESIAN STOCK MARKET DURING COVID-19

2020 to 30 June 2021. Due to the fact that there are holiday differences in each country, the data collected are 332 returns for each stock index, namely JCl, Nikkei 225, and S\&P 500.

TABLE 1. DESCRIPIVE STATISTICS OF DAILY STOCK RETURN

JCI (Indonesia) Nikkei 225 (Japan) S\&P 500 (US)

\begin{tabular}{llll} 
Mean & -0.000134 & 0.000652 & 0.000848 \\
Median & 0.000157 & 0.000297 & 0.001672 \\
Standard Deviation & 0.015502 & 0.014727 & 0.020006 \\
Skewness & 0.207355 & -0.148168 & -1.001619 \\
Kurtosis & 9.329408 & 5.999873 & 13.62332 \\
\hline
\end{tabular}

Source: Processed result from Eviews 12, 2021

Table 1 above shows the mean return in the US and Japanese stock markets are positive, while the Indonesian stock market has negative mean. In regard to standard deviation, highest variance data is owned by the US, Indonesian, and Japanese market in an orderly manner. Those values are based on stock market performance during the period of Covid-19 pandemic. This is also supported by the Skewness value, where the US and Japanese market have negative values which illustrate that this asymmetric distribution is leaning to the left, and the Indonesian market has positive value which means the asymmetric data distribution is leaning to the right. Kurtosis values in all three markets are more than 3 which show that the distribution is in peak shape instead of normal distribution.

TABLE 2. RETURN SPILLOVER BETWEEN THE US AND INDONESIAN STOCK MARKET Granger-Causality Test

\begin{tabular}{lll}
\hline Hypothesis H0 & S\&P 500 returns does not Granger & JCI returns does not Granger Cause \\
& Cause JCI returns & S\&P 500 \\
F-Statistic & 14.1748 & 0.26770 \\
Probability & 0.00001 & 0.7653 \\
\hline
\end{tabular}

Source: Processed result from Eviews 12, 2021

TABLE 3. RETURN SPILLOVER BETWEEN THE JAPANESE AND INDONESIAN STOCK MARKET

\begin{tabular}{lll}
\hline & \multicolumn{2}{c}{ Granger-Causality Test } \\
\hline Hypothesis H0 & Nikkei 225 returns does not Granger & JCI returns does not Granger Cause \\
& Cause JCI returns & Nikkei 225 \\
F-Statistic & 9.69310 & 0.62017 \\
Probability & 0.00008 & 0.5385 \\
\hline
\end{tabular}


Dewi, C., Kurniasari, F., Dewi, H., Endarto, E., Nizar, N.

RETURN SPILLOVER BETWEEN THE U.S., JAPANESE, AND INDONESIAN STOCK MARKET DURING COVID-19

Source: Processed result from Eviews 12, 2021

TABLE 4. RETURN SPILLOVER BETWEEN THE JAPANESE AND US STOCK MARKET Granger-Causality Test

\begin{tabular}{lll}
\hline Hypothesis H0 & Nikkei 225 returns does not Granger & $\begin{array}{l}\text { S\&P 500 returns does not Granger } \\
\text { Cause S\&P 500 }\end{array}$ \\
F-Statistic & 7.32875 & 16.8001 \\
Probability & 0.00001 & 0.0008 \\
\hline
\end{tabular}

Source: Processed result from Eviews 12, 2021

Return time series from the US, Japanese, and Indonesian stock markets are examined using Grangercausality test where the determined lagged value is 2 for all stock market indexes. Table 2 is discussing return spillover from the US and Indonesian stock market and with a significance rate of $1 \%$, the probability is 0.0000 less than $1 \%$ for the US to Indonesian stock market, but not the other way around (probability 0.7653 more than $1 \%$ for Indonesian to US stock market). This illustrates that $\mathrm{H} 1$ is accepted, that there is a causal relationship between the US and Indonesian stock market, along with the research done by Ishfaq \& Rehman (2018) which stated that the US stock index has a relationship with the Pakistani stock market.

Consequently, there is a probability of 0.0000 less than $1 \%$ for the Japanese and Indonesian market which means that there is a causal relationship between the Japanese and Indonesian market. But at the same time there is no such relationship between Indonesian and Japanese markets because the probability is 0.5358 more than $1 \%$. This goes along with the result (Ngunyen \& Lee, 2018) that the Japanese stock market influences the developing country stock market, namely Vietnam. The result indicates that $\mathrm{H} 2$ is accepted.

Last but not least, the Granger-causality test result between the US and Japanese market is probability $0.0000 ; 0.0000$ less than $1 \%$. This indicates that $\mathrm{H} 3$ which stated that there is a causal relationship between the US and Japanese stock market is accepted. This finding is supported by Hu et al. (1998) as the US affected the Japanese stock market especially after the monetary crisis. This finding is supported by Balli et al. (2020) and Liu \& Harmoni (2020), that stated NZ equity sectors and NZSE receive much stronger and more pronounced spillover effects from US compared to the local counterpart and the total spillovers of return and volatility stock markets in the US are higher than those in Europe. 


\section{DISCUSSION}

Results above showed that the index return for the US stock market (S\&P 500) and Japanese stock market (Nikkei 225) are the factors predicting the index return for the Indonesian stock market (JCl). Regarding The Efficient Market Hypothesis, all stock market observed in this research, namely US, Japanese, and Indonesian, are affected by historical data, public and private information so it can be said that those markets can be described as the perfect market because of the fact that all provided information can move the stock prices. Drawing your attention to that not long after the first Covid-19 case announcement in the US, S\&P 500 indexes declined, just like how it was also in Japan and Indonesia. For example, as we can see in Indonesian stock market where all information related to Coronavirus disease such as infected case news can cause a decrease in JCl's performance for the reason that investors see society's consumption rate has not recovered yet, which automatically will obstruct the country's economy growth in general. On top of it, we all know that after the increasing number of Covid19 recovery cases in Indonesia, investors are keen on buying stocks so the JCl's performance is continuously increasing. This claim is supported by Rahmayani \& Oktavilia (2020), about the existence and effect of Covid-19 pandemic on the stock market over the long-term and short-term in Indonesia. It is found that the higher total cumulative cases of Covid-19 has been the main cause of Indonesian stock market weakening in the long-term.

Volatility spillover between stock market and foreign exchange market in Indonesia (Wiryono, Widjonarko, 2009), in the research journal it was found that the US and Japan exchange rate has a significant explanatory power to the volatility of Jakarta Stock Indices. The IHSG movement also has a significant explanatory power to the volatility of Japan and US exchange rate. According to Badan Koordinasi Penanaman Modal (BKPM) Indonesia, the US is one of the largest foreign investors in Indonesia. Because Indonesia's population is quite large, the consumer and production base can be expanded. Also it can be concluded that the US economic situation will influence the decisions of US investors. Therefore, if the US economic condition is bad, it will affect their policies in investing in Indonesia.

\section{CONCLUSION}

This research analyzes the return spillover on three stock indexes in different countries, namely: United States (S\&P 500), Japan (Nikkei 225), and Indonesia (JCl) during the peak period of Covid-19 pandemic from 1 January 2020 to 30 June 2021. We use Granger-causality test to examine the return spillover between these stock indexes (Granger, 1969). Based on the findings and results, we confirm that the daily stock return shows a positive mean for US and Japan, on the other hand Indonesia shows a negative return mean. Results show that Japanese stock return has a causal relationship to Indonesia stock market 
with a significance rate of $1 \%$. This actively illustrates that there is a return spillover between the Japanese and Indonesian stock market so that the stock return in Japan influences stock market return in Indonesia. Moreover, results also show that there is a bidirectional causal relationship between the US and Japanese stock market, which means that the stock return in US influences stock return in Japan, vice versa. These findings have some important implications for the investors and policymakers. Firstly, investors have to keep themselves informed about the US and Japanese stock market when investing in the Indonesian market. Secondly, short-term investors should diversify their portfolio when buying Indonesian stocks, especially the US and Japanese investors. Lastly, policymakers have to pay more attention to economic information in US and Japan before making a decision regarding the Indonesian stock market.

This research has one limitation. This research only investigated the return spillover in the US, Japanese, and Indonesian stock market during the Covid-19 pandemic. The future research should address this and hopefully can examine not only return but also volatility spillover in Indonesia and other countries, not only during the pandemic period but also after.

\section{REFERENCES}

Admati, A.R. \& Pfleiderer, P. (1988). A Theory of Intraday Patterns: Volume \& Price Variability. The review of Financial Studies 1(1): 3-40.

Ali, N., Nassir, A., Hassan, T. \& Abidin, S. (2021). Short-run stock overreaction: Evidence from Bursa Malaysia. International Journal of Economics \& Management, 4(2): 319- 333.

Al-yahyaee, K. H., Tiwari, A. K., Al-Jarrah, I. D. W \& Mensi, W. (2019). Testing for the Granger-causality between returns in the U.S. \& GIPSI stock markets. Physica A: Statistical Mechanics \& its Applications 531.

Avalos, F., \& Zakrajsek, E. (2020). Covid-19 \& SARS: what do stock markets tell us?. BIS Quarterly Review.

Balli, F., Balli, H.O., Hasan, M., Gregory-Allen, R. (2020). Economic policy uncertainty spillover effects on sectoral equity returns of New Zealand. Journal of Economics \& Finance, 44(4): 670-686.

Barry, H. (2015). Analisis Spillover Terhadap Pasar Ekuitas Negara Berkembang Dan Negara Maju Periode 2003-2011. Ekonomi dan Bisnis, 14 (1): 21-34.

Brooks, C. (2008). Introductory Econometrics for Finance. New York, NY: Cambridge University Press.

Caramazza, F., Ricci, L. \& Salgano R. (2004). International financial contagion in currency crises. Journal of International Money \& Finance 23: 51-70.

Choo, W., Loo, S., Ling, L. \& Ung, S. (2011). Return \& Volatility Spillover between Large \& Small Stocks in Bursa Malaysia, International Journal of Business \& Social Science, 2(2): 176-185.

Ciner, C. (2011). Commodity prices \& inflation: Testing in the frequency domain. Research in International Business \& Finance, 25 (3): 229-237.

Fama, E. (1991). Efficient Capital Markets II. Journal of Finance, 46: 1575-1617. 
Granger, C.W.J. (1969). Investigating Causal Relations by Econometric Models \& Cross Spectral Methods. Econometrica, 37(3): 424-438.

Gujarati, D. (2004), Basic Econometrics, 4th Edition, McGraw Hill, India.

Hestiawan, L. \& Prijadi, R. (2020) Return Spillover of Asian REITs. Faculty of Economics \& Business, Universitas Indonesia, Indonesian Capital Market Review, 12: 93 - 106.

Hu, J.W.S., Chen, M.Y., Fok, R.C.W. \& Huang, B.N. (1998) Causality in volatility \& volatility spillover effects between US, Japan \& four equity markets in the South China Growth Triangular. Journal of International Financial Markets, Institutions \& Money, 7: 35I-367.

Hung, N.T. \& Vo, X.V. (2021). Directional spillover effects \& time-frequency nexus between oil, gold \& stock markets: Evidence from pre \& during COVID-19 outbreak, International Review of Financial Analysis 76 .

Hung, N.T. (2021). Directional Spillover Effects Between BRICS Stock Markets \& Economic Policy Uncertainty, Asia-Pacific Financial Markets, 28(3): 429-448.

Huo, R., \& A. D. Ahmed. (2018). Return \& volatility spillovers effects: Evaluating the impact of ShanghaiHong kong stock connect. Economic Modelling, 61: 260-72.

Ishfaq, M., \& Rehman, A. (2018). Global volatility spillover in Asian financial markets. Mediterranean Journal of Social Sciences, 9 (2): 109-16.

Jebran, K. \& Iqbal, A. (2016). Dynamics of Volatility spillover between stock market \& foreign exchange markets: Evidence from Asian Countries. Financial Innovation, 2: 29-48.

Joshi, P. (2011). Return \& Volatility Spillover among Asian Stock Markets. SAGE Open.

King \& Wadhani, (1990). Transmission of volatility between stock markets. The review of financial studies 3: 3-33.

Kyle, A.S. (1985). Continous Auctions \& Insider Trading. Econometrica, 53 (6): 1315-1335.

Liu, T. \& Hamori, S. (2020). Spillovers to renewable energy stocks in the US \& Europe: Are they different? Energies, 13(12).

Mala, R. \& Reddy, M. (2007). Measuring stock market volatility in an emerging economy, International Research Journal of Finance \& Economics, 8: 126-133.

Ngunyen, M.K. \& Lee, D.N. (2018). Return spillover form the US \& Japanese Stock Markets to the Vietnam Stock Market: A Frequency-domain Approach. Emerging Markets Finance \& Trade: 1-12.

Nikmanesh. L., Mohd Nor, A.H S., Sarmidi. T. \& Janor, H. (2014). Return \& Volatility Spillovers Between the US, Japanese \& Malaysian Stock Markets. Jurnal Pengurusan, 41: 101-111.

Pakpahan, K. (2003). Strategi Investasi di Pasar Modal. Journal The Winners, 4 (2): 138-147.

Panda, A.K., Panda, P., Nanda, S. \& Parad, A. (2021). Information bias \& its spillover effect on return volatility: A study on stock markets in the Asia-Pacific region, Pacific Basin Finance Journal 69.

Panda, P. \& Thiripalraju, M. (2018) Return \& volatility spillovers among stock markets: BRICS countries experience. Afro-Asian J. Finance \& Accounting 8 (2)

Qarni, M.O. \& Gulzar, S. (2020). Intra-EMU \& non-EMU, EU stock markets' return spillover: evidence from ESDC, Empirica, 47(3): 543-577.

Rahmayani, D. \& Oktavilia, S. (2020) Does the Covid-19 Pandemic Affect the Stock Market in Indonesia?. Jurnal IImu Sosial dan IImu Politik, 24(1): 33-47.

Rakhmawati, D. \& Nurhalim, M. (2021). Prediksi harga emas berjangka di masa p\&emic covid-19 menggunakan model tren deterministik, Akuntable Jurnal Akuntansi dan Keuangan, 18(1): 146152. 
Roni, B., Abbas, G. \& Wang, S. (2018) Return \& Volatility Spillovers Effects: Study of Asian Emerging Stock Markets, Journal of Systems Science \& Information, 6(2): 97-119.

Shahzad, S.J.H., Bouri, E., Kristoufek, L. \& Saeed, T. (2021). Impact of the COVID-19 outbreak on the US equity sectors: Evidence from quantile return spillovers. Financial Innovation, 7(1): 14

Shiyammurti, N. R., Saputri, D. A. \& Syafira, E. (2020). Dampak Pandemi Covid-19 di PT. Bursa Efek Indonesia (BEI). Journal of Accounting Taxing \& Auditing (JATA) 1(1).

Sun, X., Wang, J., Yao, Y., Li, J., Li, J. (2020). Spillovers among sovereign CDS, stock \& commodity markets: A correlation network perspective, International Review of Financial Analysis 68.

Uzonwanne, G. (2021). Volatility \& return spillovers between stock markets \& cryptocurrencies, Quarterly Review of Economics \& Finance, 82: 30-36.

Výrost, T., Lyócsa, S. \& Baumöhl, E. (2015). Granger causality stock market networks: Temporal proximity \& preferential attachment, Physica A: Statistical Mechanics \& its Applications, 427(), 262-276.

Wang, L. (2014). Who Moves East Asian Stock markets? The role of the 2007 - 2009 global financial crisis, Journal of International Financial Markets, Institutions \& Money, 28: 182-203.

Wang, Y. \& Liu, L. (2012). Spillover effect in Asian financial markets: AVAR structural GARCH Analysis. China Finance International, 6(2): 150-176.

Worldometer (2021). Coronavirus Updates. retrieved February 21, 2021 from; https://www.worldometers.info/coronavirus/.

Wiryono, S.K \& Widjonarko, Y.E. (2009). Volatility Spillover Between Stock Market \& Foreign Exchange Market in Indonesia, School of Business \& Management Insult Teknologi B\&ung ume 8 (2).

Yan, H., Tu, A., Start, L. \& Zhang, Q. (2020). Analysis of the EĐect of COVID- 19 on the Stock Market \& Potential Investing Strategies.

Yousaf, I., Ali, S., \& Wong, W.K. (2020). Return \& Volatility Transmission between World-Leading \& Latin American Stock Markets: Portfolio Implications, Journal of Risk \& Financial Management, 13(7), 148

Zhou, X., Zhang, W. \& Zhang, J. (2012). Volatility spillovers between the Chinese \& world equity markets. Pacific-Basin Finance Journal, 20 (2): 247-270

Zhou, P., Lu, F. \& Wang, S. (2014). Testing linear \& nonlinear granger causality in CSI300 futures \& spot markets based on new concepts of nonlinear positive/negative spillover, Journal of Systems Science \& Complexity, 27 (4): 729-42 